\title{
CIRCADIAN PATTERN OF DEEP VEIN THROMBOSIS - TRUE OR FALSE
}

\author{
Zoran Damnjanović
}

\begin{abstract}
Depending on the pattern length, biological rhythms are divided into three main categories: circadian rhythms (a 24 hour period), ultradian rhythms (a period of less than 24 hours) and infradian rhythms (a period longer than 24 hours). The cardiovascular system is organized on the basis of the weather conditions that oscillate in nature due to which most of the functions follow circadian and seasonal rhythms. The patterns of the maximum and minimum values of the cardiovascular system functions such as blood pressure, heart rate, vascular tone, coagulation and fibrinolysis are well known. Understanding the circadian pattern contributes to the additional clarification of deep vein thrombosis (DVT) pathogenesis and provides the ability to prevent the occurrence of DVT more effectively due to the predictability of critical periods during the day for the origin of an increase in the risk of DVT.
\end{abstract}

Acta Medica Medianae 2018;57(4):67-70.

Key words: circadian pattern, deep vein thrombosis, pathogenesis

Clinic of vascular surgery, Clinical Center of Niš, Serbia

Contact: Zoran Damnjanović

Bulevar Zorana Djindjića 48, 18000 Niš, Serbia

E-mail: damnjanovicz@yahoo.com

\section{Introduction}

Depending on the pattern length, biological rhythms are divided into three main categories: circadian rhythms (a 24 hour period), ultradian rhythms (a period of less than 24 hours) and in-fradian rhythms (a period longer than 24 hours). If under certain experimental conditions the biological organism got isolated from the synchronizing environmental sensitivity changes, some of the circadian rhythms would disappear. On the other hand, the endogenous circadian rhythms would continue to exist even under these conditions, but they wouldn't be connected to the day and night change pattern (1).

The cardiovascular system is organized on the basis of the weather conditions that oscillate in nature due to which most of the functions follow circadian and seasonal rhythms. The patterns of the maximum and minimum values of the cardiovascular system functions such as blood pressure, heart rate, vascular tone, coagulation and fibrinolysis are well known. Besides, there is a growing body of evidence supporting the existence of correlation between the time of day, day of the week, months of the year and both morbidity and mortality of certain cardio- vascular diseases (2). These patterns exist as a result of the interaction of the rhythms of causal factors of diseases and physiological rhythms of the body. The interactions define the chronorisk concept where the causative factor is probably not powerful enough to bring to the formation of the disease, but in a certain period of time it becomes efficient (3).

\section{Circadian pattern and deep vein thrombosis}

The biological mechanisms causing circadian variations are poorly understood. As already known, the circadian rhythm is generated by a central circadian oscillator in the suprachiasmatic nucleus of the hypo-thalamus. Studies in the field of biological rhythms over the last decade have shown that the circadian rhythm in biological, physiological, and behavioral processes has been found in mammals, animalia and plantae organisms (4). The circadian rhythm controls various biological functions in mammals including xenobiotic metabolism and detoxification, immune functions, cell cycle events, apoptosis and angiogenesis. The importance of the circadian rhythm is well known in the chronopharmacology that deals with the biological rhythm dependencies of drugs and examines circadian variations of drug (5). This suggests that chronotherapeutic approaches should be taken for many drugs to enhance their effectiveness. Currently chronotherapeutic approaches are successfully applied in the treatment of peptic ulcer, asthma bronchiale, angina inversa, migraine, allergic rhinitis, rheumatic gout, depressive illness, cardiac infarct, brain infarct, osteoarthropathy and cutaneous hypersensitivity $(6,7)$. Circadian rhythms are controlled by a cyclical expression of circadian genes. Mutations in these genes lead to the modification and/or disruption of the circadian oscillator. The 
investigation of novel genes involved in circadian rhythm - related disease will open up new possibility for therapy and they can be used as markers for improved diagnosis and prognosis (8).

As circadian rhythms modulate vital processes, it is not surprising that several health problems can be associated with the disruption of these rhythms in humans including: gastrointestinal, menstrual irregularities, and sleep disorders (9), but in the past few years, special attention has been paid to the impact of circadian rhythms on the development of deep vein thrombosis (DVT).

The research conducted in Italy by Bilora et al. (10), which included 212 patients diagnosed with deep vein thrombosis and pulmonary embolism (PE) proved the existence of peak for DVT manifestation at $12: 26 \mathrm{~h}$, while the most cases of PE were recorded at $10: 26 \mathrm{~h}$. The research conducted by Gallerani et al. (11), which included the analysis of autopsy findings of 507 patients with sudden death in the period from 1983 to 1989 , confirmed that the morning hours was the time when the peak for PE occurrence was recorded.

The inflammatory process of DVT pathogenesis involves neutrophils, lymphocytes, platelets, and the integrin subunits $\beta 2$ and $\beta 3$, which are connected to their ligands (12). The data found in experimental studies concerning the existence and impact of neutrophil extracellular traps in thrombus formation, have also been confirmed in the researches that involved patients with DVT. It is believed that the role of neutrophil extracellular traps is very important in the formation and maturation thrombus $(13,14)$. The contribution of erythrocytes in the inflammatory pathogenesis of DVT has not been fully understood yet, despite the well-known fact that large amounts of these blood cells are present at an early stage of DVT (15). Erythrocyte cytoplasm is rich in iron which, due to its oxidative effects, can have highly inflammatory impact on the endothelium if released in the circulation. Hypothetically, it is considered that in the case of thrombus formation, oxidative radicals produced by leukocytes and endothelial cells of blood vessels lead to oxidation of hemoglobin from erythrocytes and the formation of methemoglobin. Methemoglobin contains $\mathrm{Fe}^{3+}$ ions that may have an inflammatory effect on the endothelium (16).

The circadian variation of blood coagulation and of the fibrinolytic system suggest a passable state of hypercoagulability in the morning hours. Literature data suggest a tendency to an increased coagulation in the morning hours, which matches the results of this study which show the correlation of the incidence with the time of DVT occurrence in lower limbs. The existence of the morning DVT peaks can be found in the literature data concerning the confirmed endogenous circadian rhythm of blood elements and enzymes. The research conducted by Scheer et al. (17) proved the morning peak activities of platelets (09:00h), with the most expressed aggregation tendency compared to the rest of the day. Recent studies have established that, of the known components of the fibrinolytic system, only tissuetype plasminogen activator and its fast-acting inhibitor, plasminogen activator inhibitor-1, show a marked circadian variation in plasma (18). Studies have shown that the inhibitor of plasminogen activator being an important inhibitor of fibrinolysis, expresses the peak of its activity in the morning (06:30h), which may also explain the increased blood thrombogenicity in the morning $(19,20)$. Additionally, the morning peak has been identified for the value of coagulation factors VIIa and fibrinogen, as well as for coagulation inhibitors such as protein $\mathrm{C}$, protein $\mathrm{S}$, and antithrombin III (21). The studies that included healthy volunteers have shown decline in endothelial function in the morning, while the blood pressure, heart rate and activity of the renin-angio-tensin-aldosterone system have been increased $(17,19)$.

Experiments conducted by Pinotte et al. in transgenic mice and in vitro studies demonstrated that variations of coagulation factor VII were controlled at the transcriptional level through the recruitment of circadian transcription factors $(20,22)$. It was noticed that deletion or mutation of circadian transcription factors in mice changed the time to thrombotic vascular occlusion (23). Conducted studies indicate that blood coagulation is influenced by endogenous biological clocks and daylight, because circadian variations of mRNA expression of coagulation and fibrinolytic factors have been demonstrated in several murine organs $(22,24)$. Scheer et al. found that other cardiovascular risk factors are under direct circadian control, including platelet activation, count, and aggregability, plasma epinephrine and norepinephrine, plasma cortisol, systolic and diastolic blood pressure, heart rate, and vagal cardiac modulation (19). On the other hand, some investigation showed that melatonin could be important signaling molecule for circadian rhythms of many biological processes, including arterial an venous thromboembolic episodes, indicating an association between blood clotting mechanisms and daylight patterns $(25,26)$.

Previous investigations on the territory of Southern Serbia have revealed a seasonal pattern of the lower limb DVT appearance, with the highest incidence during the cold period of the year (OctoberMarch) (27). The connection between the DVT pathogenesis and the change of external temperature and atmospheric pressure has also been proven. This connection depends on the patient age and the thrombus localization $(28,29)$.

\section{Conclusion}

Further studies should additionally clarify the reasons for circadian DVT rhythm in the lower limbs. Understanding the circadian pattern contributes to the additional clarification of DVT pathogenesis and provides the ability to prevent the occurrence of DVT more effectively due to the predictability of critical periods during the day for the origin of an increase in the risk of DVT. 


\section{References}

1. Manfredini R, Manfredini F, Malagoni AM, Boari B, Salmi R, Dentali $F$ et al. Chronobiology of Vascular Disorders: a "Seasonal" Link between Arterial and Venous Thrombotic Diseases? JDC 2010; 2(1): 61-7.

2. Takeda N, Maemura K. Circadian clock and cardiovascular disease. J Cardiol 2011; 57(3):249-56. [CrossRef][PubMed]

3. Dentali $F$, Manfredini $R$, Ageno W. Seasonal variability of venous thromboembolism. Curr Opin Pulm Med 2009; 15(5):403-7. [CrossRef][PubMed]

4. Baggs JE, Hogenesch JB. Genomics and systems approaches in the mammalian circadian clock. Curr Opin Genet Dev 2010; 20: 581-7. [CrossRef][PubMed]

5. Ozturk N, Ozturk D, Kavakli I H, Okyar A. Molecular Aspects of Circadian Pharmacology and Relevance for Cancer Chronotherapy. Int J Mol Sci 2017; 18(10): 2168. [CrossRef][PubMed]

6. Ando $H$, Otoda $T$, Ookami $H$, Nagai $Y$, Inano $A$, Takamura $T$, et al. Dosing time-dependent effect of raloxifene on plasma plasminogen activator inhibitor-1 concentrations in post-menopausal women with osteoporosis. Clin Exp Pharmacol Physiol 2013; 40: 227-32. [CrossRef][PubMed]

7. Martinod K, Demers M, Fuchs TA, Wong SL, Brill A, Gallant $M$, et al. Neutrophil histone modification by peptidylarginine deiminase 4 is critical for deep vein thrombosis in mice. Proc Natl Acad Sci U S A 2013; 110: 8674-9. [CrossRef][PubMed]

8. Shanmugam V, Wafi A, Al-TaweelN, Büsselberg D. Disruption of circadian rhythm increases the risk of cancer, metabolic syndrome and cardiovascular disease. Journal of Local and Global Health Science 2013; 3: $2-42$.

9. Srinivasan V, Singh J, Pandi-Perumal SR, Brown GM, Spence DW, Cardinali DP. Jet lag, circadian rhythm sleep disturbances, and depression: the role of melatonin and its analogs. Adv Ther 2010; 27(11): 796813. [CrossRef][PubMed]

10. Bilora F, Manfredini R, Petrobelli F, Vettore G, Boccioletti V, Pomerri F. Chronobiology of nonfatal pulmonary thromboembolism. Panminerva Med 2001; 43 (1): 7-10. [PubMed]

11. Gallerani M, Manfredini R, Ricci L, Grandi E, Cappato $R$, Calò $G$, et al. Sudden death from pulmonary thromboembolism: chronobiological aspects. Eur Heart J 1992; 13(5): 661-5. [CrossRef][PubMed]

12. Wang LM, Duan QL, Yang F, Yi XH, Zeng Y, Tian HY, et al. Activation of circulated immune cells and inflammatory immune adherence are involved in the whole process of acute venous thrombosis. Int J Clin Exp Med 2014; 7(3): 566-72. [PubMed]

13. Martinod K, Wagner DD. Thrombosis: tangled up in NETs. Blood 2014; 123(18): 2768-76. [CrossRef][PubMed]

14. Geddings JE, Mackman N. New players in haemostasis and thrombosis. Thromb Haemost 2014; 111(4): 5704. [CrossRef][PubMed]

15. Turitto VT, Weiss $\mathrm{HJ}$. Red blood cells: their dual role in thrombus formation. Science 1980; 207(4430): 5413. [CrossRef][PubMed]

16. Woollard KJ, Sturgeon S, Chin-Dusting JP, Salem HH, Jackson SP. Erythrocyte hemolysis and hemoglobin oxidation promote ferric chloride-induced vascular injury. J Biol Chem 2009; 284(19): 13110-8. [CrossRef][PubMed]

17. Scheer FA, Michelson AD, Frelinger AL 3rd, Evoniuk $H$, Kelly EE, McCarthy $M$, et al. The human endogenous circadian system causes greatest platelet activation during the biological morning independent of behaviors. PLoS One 2011; 6(9): e24549.

[CrossRef][PubMed]

18. Andreotti F, Kluft C. Circadian variation of fibrinolytic activity in blood. Chronobiol Int 1991; 8(5): 336-51. [CrossRef][PubMed]

19. Scheer FA, Shea SA. Human circadian system causes a morning peak in prothrombotic plasminogen activetor inhibitor-1 (PAI-1) independent of the sleep/wake cycle. Blood 2014; 123(4): 590-3. [CrossRef][PubMed]

20. Schoenhard JA, Smith LH, Painter CA, Eren M, Johnson $\mathrm{CH}$, Vaughan DE. Regulation of the PAI-1 promoter by circadian clock components: differential activation by BMAL1 and BMAL2. J Mol Cell Cardiol 2003; 35(5): 473-81. [CrossRef][PubMed]

21. Koukkari WL, Sothern RB. Introducing biological rhythms: a primer on the temporal organization of life, with implications for health, society, reproduction and the natural environment. New York: Springer; 2006.

22. Pinotti M, Bertolucci C, Portaluppi F, Colognesi I, Frigato E, Foa A, et al. Daily and circadian rhythms of tissue factor pathway inhibitor and factor VII activity. Arterioscler Thromb Vasc Res 2005; 25: 646-9. [CrossRef][PubMed]

23. Westgate EJ, Cheng Y, Reilly DF, Price TS, Walisser JA, Bradfield CA et al. Genetic components of the circadian clock regulate thrombogenesis in vivo. Circulation 2008; 117: 2087-95. [CrossRef][PubMed]

24. Oishi K, Koyanagi S, Ohkura N. Circadian mRNA expression of coagulation and fibrinolytic factors is organ-dependently disrupted in aged mice. Exp Gerontol 2011; 46: 994-9. [CrossRef][PubMed]

25. Dahm A, Osterud B, Hjeltnes N, Sandset PM, Iversen PO. Opposite circadian rhythms in melatonin and tissue factor pathway inhibitor type 1 : does daylight affect coagulation? J Thromb Haemost 2006; 4: 18402. [CrossRef][PubMed]

26. Pogan $L$, Bissonnette $P$, Parent $L$, Sauve R. The effects of melatonin on $\mathrm{Ca}(2+)$ homeostasis in endothelial cells. J Pineal Res 2002; 33: 37-47.

[CrossRef][PubMed]

27. Damnjanovic $Z$, Jovanovic M, Ilic N, Bogdanovic D, Kudumovic $M$, Kamenov $A$, et al. Seasonal variations in the incidence of idiopathic lower extremity deep vein thrombosis on the territory of South Serbia. HealthMED 2012; 6(7): 2477-81.

28. Damnjanović $Z$, Jovanović $M$, Bogdanović $D$, Smiljković I, Ilić N, Damnjanović I. Relationship between the incidence of idiopathic lower extremity deep vein thrombosis and the location of the thrombus with changes of atmospheric pressure. Chirurgia (Bucur) 2012; 107 (4): 483-7. [PubMed]

29. Damnjanović $Z$, Jovanović $M$, Stojanović $M$, Radojković $M$, Bogdanović $D$, Potić $M$, et al. Age Dependent Influence of external temperature on the pathogenesis of idiopathic lower extremity deep vein thrombosis. Chirurgia (Bucur) 2013; 108(4): 530-4. [PubMed] 
Revijalni rad

UDC: 616.14-005.6-092

doi: $10.5633 / \mathrm{amm} .2018 .0409$

\title{
CIRKADIJALNI OBRAZAC TROMBOZE DUBOKIH VENA - ISTINA ILI ZABLUDA
}

\begin{abstract}
Zoran Damnjanović
Klinika za vaskularnu hirurgiju, Klinički centar Niš, Niš, Srbija

Kontakt: Zoran Damnjanovic

Bulevar dr Zorana Đinđića 48, 18000 Niš, Srbija

E-mail: damnjanovicz@yahoo.com

U zavisnosti od dužine ciklusa biološki ritmovi su svrstani u tri glavne vrste: cirkadijalni (period od 24h), ultradialni (period kraći od 24h) i infradijalni (periodi duži od 24h). Kardiovaskularni sistem organizovan je na osnovu vremenskih prilika koje osciliraju u prirodi, usled čega većina funkcija prati cirkadijalni ili sezonski ritam. Obrasci maksimalnih i minimalnih vrednosti funkcija kardiovaskularnog sistema, kao što su arterijski pritisak, srčana frekvencija, vaskularni tonus, koagulacija i fibrinoliza, dobro su poznati. Poznavanje cirkadijalnog obrasca doprinosi dodatnom razjašnjenju patogeneze tromboze dubokih vena (TDV) i pruža mogućnost efikasnije prevencije nastanka TDV usled predvidljivosti kritičnih perioda tokom dana za porast rizika od nastanaka TDV.
\end{abstract}

Acta Medica Medianae 2018;57(4):67-70.

Ključne reči: cirkadijalni ritam, tromboza dubokih vena, patogeneza 